\title{
Ex-gay Rhetoric and the Politics of Sexuality: The Christian Antigay/Pro-family Movement's "Truth in Love" Ad Campaign
}

\author{
Tina Fetner, PhD \\ Cornell College
}

Tina Fetner, PhD is Assistant Professor of Sociology at Cornell College, 600 First Street West, Mount Vernon, Iowa 52314 (Email: tfetner@cornellcollege.edu).

An earlier version of this paper was presented at the 2000 meeting of the American Sociological Association. The author thanks Karen Albright, Edwin Amenta, Cindy Benton, Mary Bernstein, Lane Dunlop, Jeff Goodwin, David F. Greenberg, Michelle Mouton, Kirilka Stavreva, Jama Stilwell and the anonymous reviewers for valuable feedback on earlier drafts. 
ABSTRACT. In 1998, a coalition of antigay, pro-family activist organizations published a set of full-page print advertisements in several nationally-recognized newspapers. These ads promoted sexual ("ex-gay") conversion therapy for homosexuals. I examine these advertisements as a contest over cultural symbols and values, and over the very definition of lesbian and gay identity. This discursive contest had the potential to impact activist politics greatly, but this impact was mitigated significantly by a similar set of ads produced in response by an opposing movement: the lesbian, gay, bisexual and transgender movement. The interactive dynamics between opposing movement impact the political field in which activists on each side pursue their goals.

KEYWORDS: opposing movements, Christian Right, antigay movement, lesbian and gay rights, LGBT movement, social movements, pro-family movement, ex-gay, sexual conversion therapy 
"While I longed for a female life-partner, I knew it just wouldn't work. That's when I went home and prayed 'God, please show me who You are, and fill the void in my heart."

\author{
"wife, mother, former lesbian" Anne Paulk \\ 'Truth in Love' advertisement \\ New York Times, July 13, 1998
}

In 1998, a collection of Christian antigay, pro-family activist organizations pooled their resources to publish a series of full-page advertisements in major newspapers across the United States. These advertisements alerted their audience to religious treatment programs for homosexuals, which claimed to repair their same-gender attractions and "convert" them to heterosexual people. They featured a number of people, ex-gays and former lesbians, who had shed their homosexual orientations, gotten married and had children, but most importantly, who had restored their (necessarily) broken relationship with God. The advertisements, collectively called the "Truth in Love" campaign, asked the parents, family members, and friends of lesbian and gay people to tell them the "truth" about their sinful lifestyle and encourage them to take steps necessary to change their sexual orientation through the acceptance of Jesus Christ. The series of four print ads was followed by two television commercials promoting the same message: that ex-gays who were "converted" were happier and more fulfilled than when they were "in the lifestyle."

The advertisements sent shockwaves rippling through the press. Newsweek magazine ran a cover story on Anne Paulk and her husband, John, who also claimed to be ex-gay. ${ }^{\mathrm{i}}$ A number of newspapers printed articles questioning whether it was indeed possible for lesbians and gay men 
to "change." Television news show 20/20 ran a piece on sexual conversion. The advertisements caused a powerful but short-lived burst of national attention to the issue of sexual conversion therapy. The lesbian and gay movement responded quickly with its own full-page print ads, the first of which was in print only two days after the first ex-gay ad appeared. The responses were produced by the Human Rights Campaign Foundation, and were funded by a coalition of lesbian, gay, bisexual and transgender (LGBT) movement organizations. The response ads invoked the ex-gay ads directly, and challenged each of their claims. The lesbian and gay responses staked claims for the definitions and symbols of the ex-gay ads.

In the cultural politics of lesbian and gay rights in the 1990s, the contested discourse in these newspaper ads over lesbian and gay identities targeted the foundation of the LGBT movement's claims. The ex-gay movement claims that lesbian and gay identity does not even exist, only same-sex behaviors. How can gay rights be legislated if there is not a distinct group of (permanently) gay people? This cultural contest was a high-stakes game for LGBT movement activists, and the back and forth dialogue of these dueling advertisements raises questions for students of social movements. What are we to make of these two competing claims about sexual identity? Is this contested discourse going to set the fight for gay rights back, or is it going to propel the movement forward?

When we think of the interplay between movement and countermovement, it is generally understood that one opposing movement can create opportunities for the other to do its activism in a new way, use a new language, or operate in a new venue (Meyer and Staggenborg, 1996, 1998; Zald and Useem, 1987). There is evidence of this in the case at hand: the ex-gay advertisements invited LGBT activists to participate in a national discourse on whether or not gay and lesbian people can convert to heterosexual. This action opened the door to a broader 
public audience that otherwise would not have been so interested in lesbian and gay identity. The LGBT movement took advantage of this opportunity to present images of happy and healthy lesbian and gay people and their families to the American public. This new opportunity, however, is a limited one. When social movement activists respond to the actions of an opposing movement, they are constrained in terms of issue selection and venue. The new opportunities created by an opposing movement are not necessarily useful for pushing the agenda of a social movement forward. That is not to say that these contests are not important to social movements. Indeed, the LGBT movement was eager to respond (Birch, interview with author). This paper will take a close look at the discursive contest of these advertisements to highlight the power of language, image, and meaning in contested politics.

\section{Symbolic Contests in Social Movements}

Social constructionists tell us that symbolic contests shape the terms of public debate, and constrain our way of knowing about social problems. Joseph Gusfield $(1963,1981)$ makes the case that social conditions only come to be understood and defined as social problems under some circumstances, in particular social contexts. In this vein, a wide range of analysis has been done connecting social problems to the contests over symbols and discourse that bring them into relief (e.g., Best, 1987, 1990; Jenness, 1990, 1995). We now have a large literature pointing out the symbolic contests behind the emergence of social problems as varied as cigarette smoking (Markle and Troyer, 1979), rape (Rose, 1977), and PMS (Rittenhouse, 1992).

Social movement theory has folded some of this thinking into its understanding of the role of social movements in creating new definitions of social issues that are compatible with agendas for social change. Primarily, scholars of social movements have focused on the role of 
social movements in "framing" the issue of interest in a way that resonates with a supportive audience (Gamson, 1992; Gerhards and Rucht, 1992; Oliver and Johnston, 2000; Snow, Rochford, Worden, and Benford, 1986; Snow and Benford, 1988, 1992; Zald, 1996). From these studies, we learn that a crucial aspect of activism is changing the way people talk about particular social issues. Others interested in social movements remind us that framing is not the only aspect of culture that is relevant. Impacting culture through images and rhetoric are also critical to social change. Janice M. Irvine (2002), for example, demonstrates that language can be used to evoke particular responses from constituents. A number of scholars have reminded us of the importance of emotions in social movement activity (Goodwin, Jasper and Poletta, 2001; Jasper, 1998; Yang, 2000). Symbolic contests are often at the heart of these battles over the emotions of an audience. How language is framed, the choice of rhetoric, and the venue of the exchange are all important factors to consider as well.

Students of opposing movements are particularly well positioned to push forward the scholarly thinking on social movements and symbolic contests. With two social movements competing for both public support and political efficacy on opposite sides of an issue, symbolic and discursive contests are almost always a central feature of opposing movement politics. In earlier work (Fetner, 2001), I examine the rhetorical shifts in lesbian and gay movement claims caused by the emergence of the Christian antigay movement in the late 1970s. The antigay activists' challenges to the claims of the lesbian and gay movement changed the language, tone, and frame of pro-gay claims. Suzanne Staggenborg (1993) demonstrates that the claims and actions of the pro-life movement have created "critical events" in which supporters of the prochoice movement are inspired to participate in activism. These studies demonstrate that the symbolic and discursive components of the interactions between opposing movements are 
critical to contested politics. However, more work needs to be done to understand how these symbolic contests between opposing movements impact the political progress of each movement overall. This paper looks at a single interactive moment between two long-standing opposing movements to tease out the construction of meaning inherent to symbolic and discursive contests. It then considers how this contest impacts the political opportunities and the potential for policy change of the responding social movement. But first, I provide some background information on the relationship between ex-gay conversion therapy providers and the Christian antigay movement.

\section{Ex-gay Conversion and Antigay Activism}

The organizations that sponsored the series of advertisements were not the ex-gay conversion groups themselves, but rather were a number of social movement organizations in the Christian Right, including the Christian Coalition and a host of antigay, pro-family organizations. These activist organizations have their roots in the Christian antigay movement of the late 1970s, as well as the anti-feminist and anti-abortion movements of that era. This movement is dedicated to political activism around a host of issues, and lobbies for legislative changes supporting their socially conservative agenda.

Ex-gay groups, on the other hand, are service organizations, not activist groups. ${ }^{\text {ii }}$ They provide religious counseling to those who seek them out. These groups have existed as apolitical Christian self-help organizations since the 1970s, but they remained out of the spotlight until they were brought into mainstream public view by these advertisements. Ex-gay groups offer to "convert" gay men and lesbians who do not want to be homosexual through a process of stringent gender socialization, prayer, and group and individual counseling. Many of the 
procedures are derived from homosexual aversion therapies that have been rejected in the fields of psychology and psychiatry (for a review of aversion therapies, see Kronemeyer, 1980). Exgay organizations range from urban churches that hold weekly meetings where demons are cast out of unhappy homosexuals, to rural retreats where lesbians and gay men can live until they feel comfortable with their changed sexual orientation.

The way that ex-gay counseling groups and antigay/pro-family activist groups work together is highlighted by the "Truth in Love" ad campaign. The presence of ex-gay conversion therapy, and the successes that its advocates claim, are critical foundations for the claims of Christian antigay, pro-family movement groups. The ex-gay groups allow Christian antigay activists to condemn homosexuality without abandoning homosexual people. Through a policy of "hate the sin, love the sinner," activists can take stands against equal rights for lesbian and gay people, and respond to criticisms by offering an alternative to homosexuality.

The LGBT movement has been engaged in political battles with the Christian antigay movement since its inception. The interactive relationship between these two opposing movements has impacted their activism greatly. The LGBT movement has a long history of opposing the classification of homosexuality as a psychological disorder, and the movement has also opposed the use of aversion therapy to treat homosexuality. However, this activism was directed toward the psychological and psychiatric professional associations, not religious counselors. Prior to this advertising campaign, the LGBT movement showed little interest in debating the merits of ex-gay counseling inside the church. This ad campaign, however, made the political implications of ex-gay therapy clear to LGBT activists, and caught their attention.

Unlike much of the antigay activism of the pro-family movement, the advertising campaign by the coalition of Christian organizations was not related to a particular policy 
proposal, but rather to the cultural symbols of lesbian and gay politics as a whole. The movement had seen failures on several fronts: a direct democracy initiative opposing lesbian and gay rights in Colorado was declared unconstitutional, lobbying efforts in the Republican party in the Clinton era were unsatisfactory, and consumer boycotts of major corporations like Disney had very little impact. Given these roadblocks, leaders in the pro-family movement developed a new strategy. Formerly, pro-family activists mobilized their own constituents to support boycotts and initiative drives and lobbied political insiders for legislative changes at the federal, state, and local levels. Now, activists would attempt to directly address non-constituents, try to change their minds about the nature of sexual orientation, and call into question the authenticity of lesbian and gay identity. This strategic shift was accompanied by a tactical innovation: promoting ex-gay conversion as the central tenet of their appeal. In doing so, pro-family activists took a step back from impacting policy directly, and tried to change the terms of the debate about sexual politics. Of course, these ads clearly express an awareness of the political implications of the cultural contest in which they were engaged. One of the ex-gay ads notes,

For years Christians have taken a stand in the public square against aggressive homosexual activism...And we want to share the hope we have in Christ, for those who feel acceptance of homosexuality is their only hope (Alliance for Traditional Marriage et al., 1998b).

The ad campaign does not target the policy actions of the lesbian and gay movement, but rather the meaning of sexual identity, seeking to undermine the foundations on which the lesbian and gay movements' political claims are based.

For their part, LGBT movement organizations paid close attention to the new tactic of their opposing movement, and responded in kind. Taken together, the "Truth in Love" campaign 
and the response ads, titled "Toward Hope and Healing for America," are a capsule of the contest over the definitions, symbols and language of sexuality in this politically charged context. The two sets of advertisements can be seen as an interaction contesting the cultural meanings assigned to sexuality and vying for the ownership of a number of symbols that are highly valued by the American public: family, God, and love, among others. Moreover, the ads share the same format and overall style, which indicates that the very construction of the message itself is also being contested by these two movements.

\section{Definitions}

The ex-gay ad campaign calls into question the very definition of lesbian and gay identity. Using ex-gay conversion therapy to demonstrate that homosexuality is mutable, the campaign calls into question the lesbian and gay movements' use of "gay" and "lesbian" as valid identity categories. This strategy relies on two frames to anchor its position on homosexuality: homosexuality as choice and homosexuality as condition (Hunt, Benford and Snow, 1994; Snow and Benford, 1992). The homosexuality as choice frame denies any potential biological causes of same-sex desire. It maintains its focus on sexual acts, limiting the definition of homosexuality to the act of choosing a sexual partner. Desire, emotion and orientation are notably absent from this frame. Homosexuality is not integrated into the personality of an individual; it is simply the result of a choice of a same-sex rather than an opposite-sex partner. This frame follows the biblical interpretation that declares that a homosexual sex act is a sin. For example, televangelist Jerry Falwell uses this frame when he writes,

our Constitution holds that all men are created equal, but laws were made to deal with unequal behavior. If homosexuality is deemed normal, how long will it be 
before rape, adultery, alcoholism, drug addiction, and incest are labeled as

normal? (Falwell, 1980, pp. 183-184).

This frame was used more often in early Christian antigay activism, especially in debates about sodomy laws, though it crops up in political discourse on occasion.

The homosexuality as condition frame also denies a biological root to homosexuality, but it does acknowledge individuals' feelings of desire as integrated with their sexual identity. However, this frame refers to homosexuality as a psychological flaw caused by any of a number of childhood traumas or familial dysfunctions. Here is an example of such a frame in the first ad of the series. The speaker is ex-lesbian Anne Paulk:

I was four years old when a teenage boy molested me...By the time I hit my teens I was rough... my heart cold...I had so thoroughly rejected my own femininity that, even though I had a lot of male friends, I just wasn't attracted to men sexually. I became drawn to other women who had what I felt was missing in me (Alliance for Traditional Marriage, et al., 1998a).

This sort of story is typical of the anecdotal evidence that Christian antigay activists use to support this position. Another trope is derived from Freudian theory: the plight of the child with the absent father and overbearing mother. (This implicitly points a finger of blame at the women's movement for upsetting what pro-family activists consider to be the natural familial order). Each of these problems, in the homosexuality as condition frame, causes children to lose touch with their "natural" gender role, which would include sexual attraction to the opposite sex.

While the understanding of a condition in the medical or psychological sense would normally negate the presence of a choice, in this case, the choice and the condition frames coexist unproblematically for ex-gays and Christian antigay activists alike. The two frames fit 
together in that participation in the "homosexual lifestyle" is seen as an understandable but poor choice as a mechanism of escape from the residual pain of these childhood traumas. In this way, homosexuality is linked with promiscuity, drug and alcohol addiction, and violent outbursts (Satinover, 1996). As one of the ex-gay advertisements claims, homosexuality is "the visible response to a broken heart" (Alliance for Traditional Marriage, et al., 1998b). It is easy to see how these frames rely on the Christian Right's criticism of changing social norms that have resulted from the sexual revolution, feminism, and what these activists and many others call the "breakdown of the family." The Christian antigay, pro-family movement uses these frames to explain homosexuality, but they would not be as useful if it were not for the ex-gay conversion groups, which offer an alternative to homosexuality. It is through advocating sexual conversion that these activists can reconcile their "love the sinner, hate the sin" platform with their activism against civil rights for lesbians and gay men. The conversion programs allow Christian antigay, pro-family movement organizations to argue that civil rights only cloud the issue and that the real solution is to choose heterosexuality with the help of an ex-gay group.

The ex-gay ads attempt to reorient the discourse of "lesbian and gay" to one of "homosexuality." This shift would reverse the course of earlier discursive contests in which lesbian and gay people claimed new labels for the identities they embraced. To discuss lesbian and gay political issues in terms of homosexuality is to reassociate it with the psycho-medical establishment and the diagnosis of the disorder of homosexuality that this establishment has since abandoned. The Christian antigay activists, in the ex-gay ads and elsewhere, rely on discarded psychology theories to complement their own pseudo-scientific research which demonstrates that homosexuality really is a condition caused by a disruption in early childhood development (e.g., Bieber et al., 1962; Socarides, 1978). These theories rely heavily on an 
unsophisticated conceptualization of gender and often conflate both the cause and the expression of homosexuality with gender deviations. At the same time, however, the ads claim that lesbians and gay men choose to participate in a sinful lifestyle that heterosexual people resist. Their narrative conveys the imagery of homosexuality as both a condition and an addiction, a sinful choice made as the result of abnormal sexual development.

\section{Symbols}

The Christian antigay movement claims ownership of several symbols in these ads: church, God, family and America. These symbols are sprinkled unproblematically throughout the ex-gay advertisements. In addition, the ex-gay ads claim to be on the side of free speech, truth and love. They also invoke racial imagery and language to imply that the contest over lesbian and gay rights also divides racists from non-racists. Each of these symbols is reclaimed by the Human Rights Coalition in their response ads, which defend the principle of equal rights for lesbians and gay men. The LGBT movement refused to let these meaning-laden social symbols draw the borders between supporters and detractors of gay rights.

The primary concept that the advertisements contest is the meaning of homosexuality. However, in engaging this problem, they use the symbolic concepts God and Christianity to support their position, and in doing so, they also imply that all people of Christian faith share an antigay opinion. Here is an example from one of the ex-gay ads:

[W]hen we see great suffering among homosexuals, it's an inherent Christian calling to show compassion and concern. The truth we know is that God abhors any form of sexual sin, be it premarital sex, adultery, prostitution, or homosexuality. And if you were trapped in some self-destructive behavior, 
wouldn't you want someone to care? (Alliance for Traditional Marriage, et al., 1998b).

These use of the terms God, Christian and truth here imply that there is widespread agreement among Christians about biblical proscriptions against homosexuality, when such a consensus does not exist.

The LGBT movement response ads challenge this representation of God, presenting a more pluralistic and tolerant concept of God and religion. They speak directly to the contest over who gets to use God as a symbol in this political discussion on lesbian and gay rights. The quote below is from the first of two print ads produced in response to the ex-gay ads:

Some in this country are selling the myth that gay Americans are not people of faith. But many are deeply religious and affiliated with a rich and diverse array of institutions of faith. There are those who want to claim God and the Bible for their own narrow vision of this nation.... No one can claim an exclusive relationship with God. Most important, religious disagreement should never be used to justify discrimination (Human Rights Campaign Foundation, 1998a).

The symbolic value of family is also brought into this contest. The movement that sponsored the ex-gay ads calls itself the pro-family movement and tries to claim ownership over the definition of family according to the nuclear family model of two married, heterosexual parents and their biological or adopted children. Single parenthood, cohabitation of unmarried partners, divorce and remarriage, as well as homosexuality and bisexuality, are seen as disruptive of the appropriate structure of family. The ongoing policy battles over same-sex marriage and adoption by same-sex couples are contests over the state's approval of lesbian and gay family forms, fiercely opposed by the pro-family movement. The ex-gay ads' use of family symbolism 
is most pronounced in its "Toward a New Hope for Healing" ad, in which the parent-child relationship is defined as a quality relationship only when homosexuality is not tolerated. This ad depicts a child blowing out the candles on his birthday cake. The text of the ad is written in the voice of the now grown child's parents and tells the story of the boy's life path into the gay lifestyle and through an ex-gay conversion.

We don't question the love of any parent for their child. It was never easy telling him what he didn't want to hear...that homosexuality was sin and he needed to turn from it. We weren't being judgmental. We were just being parents...To say no to his behavior in a way that was straightforward and caring and based on the truth was simply an honest expression of our love. Who could fault us for telling the truth? (Alliance for Traditional Marriage, et al., 1998d).

Throughout this and all the other ex-gay ads are references to "the truth," meaning a singular dictum against homosexuality as the word of God. This truth is of course disputed by many, including lesbian and gay activists in their response ad. The above quote is in direct conflict with the lesbian and gay movement's ad,"The Waterbury Family," in which the exclusively heterosexual definition of family is contested, not by a same-sex partnership, but by a parentchild relationship in which the daughter is a lesbian who has the support of her parents. This ad contests the ex-gay ads' definition of parental love as drawing a line in the sand regarding a child's homosexuality, and provides an example of parental love expressed as acceptance and support of their daughter's sexual identity and life choices.

One ad in the series, featuring African-American football star Reggie White, lays claim to free speech, America and racial tolerance. The caption of this ad, "In defense of free speech," claims that lesbian and gay activists are censoring antigay opinions when they call their 
opponents names such as bigot and homophobe. This ad likens such a politically charged exchange to the stifling of dissent in China and Sierra Leone:

Our Founding Fathers knew free speech was essential to the American experiment in ordered liberty...The activist homosexual lobby has used its free speech privilege to promote its own ideas...demanding the culture hear no other view but theirs. That's not only bad for true 'tolerance,' it's also un-American...That's why all Americans should shudder when homosexual activists routinely use the tactics of threats, intimidation, blackmail and deception to strangle a free and open exchange on homosexual behavior (Alliance for Traditional Marriage, et al., 1998c).

The ad has an inset with a small picture of Reggie White and his wife, with a quote in which White says,

I've been called homophobic. I've been called stupid. I've been called unintelligent, and I've been called a nigger by so-called gay activists (Alliance for Traditional Marriage, et al., 1998c).

This quote accusing gay activists of racist attacks aligns the pro-family movement with an antiracist stance and connects the pro-family agenda with American ideals of free speech and tolerance of diverse opinions. These values, tolerance and diversity, are those that the lesbian and gay movement has claimed as its own in the past, but these advertisements contest and redefine them as Christian, pro-family principles, consistent with an antigay political position.

The lesbian and gay response ads reclaim the symbols of America, and also use an African-American man, Stampp Corbin, as a spokesperson for this effort. The ads connect the lesbian and gay rights movement with the civil rights movement of the 1960s, in order to address 
the racial issues brought in by the ex-gay ads. The ad begins,

Hello. My name is Stampp. I'm a computer executive. I work hard. I live in the heartland of America. I love to swim and run. And, oh, yes, I happen to be gay (Human Rights Campaign Foundation, 1998b).

Later in the ad, Corbin talks about telling his mother he was joining the lesbian and gay movement:

She explained that if she had not participated in the black civil rights movement in the early 1960 s, she would have regretted it for the rest of her life. She was glad that in the 1990s, I had found my voice and the courage to speak out for the equality gay people deserve (Human Rights Campaign Foundation, 1998b).

These symbolic battles draw the lines between pro-gay and antigay. It is hoped by both sides that readers who are undecided about gay rights legislation, for example, will already have a strong opinion about religion, civil rights, or the principle of free speech. The use of meaningful symbols by one side of an opposing movement battle implies that to continue caring about the symbols in question, one must adopt the perspective of that side of the issue. Knowing this, each side makes attempts to "own" a number symbols that touch upon closely held values of a public audience (Gusfield, 1981).

\section{Style}

The cultural contest in these newspaper advertisements involves definitions, symbols, language, and style. For example, the first ad produced by each of these opposing movements, the ex-gay ad featuring Anne Paulk (Alliance for Traditional Marriage, et al., 1998a), and the pro-gay ad featuring the Waterbury family (Human Rights Campaign Foundation, 1998a), use a 
virtually identical format (see Appendix for ad re-prints). Like all the ads in these series, they feature a photo over text, a two-column format, bold headers breaking up the text, a personal testimony writing style, the "if you really love someone" slogan, and even the formatted list of sponsoring organizations. The list of similarities could go on: the photo caption, the family portrait style of the photograph, and even the font of the typeface of the ex-gay ad was appropriated by the lesbian and gay ad. Clearly, the Human Rights Campaign Foundation was not willing to hand over ownership of any part of this message to the ex-gay movement unchallenged.

Their duplication of the style, as well as much of the content, of the ex-gay ads, is a manifestation of the interactive relationship between these opposing movements. The layout of the responding advertisements would capture the eye of anyone familiar with the ex-gay ads, thus establishing a context for the reader. Next, each claim of the ex-gay ads was refuted by the pro-gay response, both visually and in the text. Finally, the logic of the argument claims that gay rights are indeed consistent with American and Christian values. The claims of the response were formulated specifically to address the claims of the ex-gay ads. Of course, the ex-gay ads themselves respond directly to earlier claims of the lesbian and gay movement.

\section{Symbolic Contests in Opposing Movement Politics}

Why would the lesbian and gay social movement organizations that sponsored the ads participate in this type of activism, a battle of words and meanings, rather than use all of the funds spent on these responses to lobby legislators over policies that would impact lesbians and gay men more directly? The Human Rights Campaign Foundation and its co-sponsoring LGBT movement organizations felt that this was a critical conflict, which might change the focus of 
lesbian and gay activism in the future. Elizabeth Birch, Executive Director of the Human Rights Campaign, claims that this could have marked a major discursive shift, especially for parents with gay and lesbian children:

At the time, we didn't know if in fact... message like this would really resonate with, say, parents of lesbian and gay kids. Would this be a potent new form of hope for them that they could keep their kids from being gay? (interview with author).

Indeed, it was not so long ago when the psychological model was the primary frame through which homosexuality was understood, even by homosexual people themselves. Re-adopting this frame, in which homosexuality was defined as an abnormal, unhealthy orientation, would be a major step backward for lesbian and gay activism. More than this, however, changing the discourse would undermine the claims of the lesbian and gay movement, whose platform of inclusion, citizenship, and rights for lesbians, gay men, bisexuals, and transgender people rests upon a symbolic foundation that understands LGBT people to be an oppressed minority group worthy of full citizenship. If the challenge posed by the Christian antigay, pro-family movement were to successfully redefine homosexuality as a curable pathology, it would not only deny rights to lesbians and gay men, but it would label them sexual deviants. Thus, the movement had little choice: if they were to continue their activism, they were going to need to address these claims.

But the forum for responding to the ex-gay ads' claims did not necessarily provide an opportunity for the LGBT movement to stake any new claims of its own. Opposing movement organizations adjust their activism to respond to the activities of their opponents in direct, issuespecific ways (Fetner, 2001). That is, if antigay activists make a claim that homosexuals should 
not have "special rights," they open up an opportunity for the LGBT movement to direct additional activism toward rights-based claims. The new claim introduced by the Christian antigay, pro-family movement, that homosexuals can and should change their orientation, similarly limited the scope of the pro-gay response. In making a claim that lesbians and gay men do not need to change into heterosexuals, the response ads promoted very little of the LGBT movement's political agenda. There was no mention of any pending legislation or any proposals for change. There was no discussion of diversity, sexual variety, or inclusiveness. The response ads featured one lesbian and one gay man, both of whom intentionally appear middle-class and "middle-American" (Birch, interview with author). In this forum, there was no room to discuss bisexuality or gender identity. Being in the position of responding, rather than setting the agenda, the Human Rights Campaign Foundation chose to focus on the issues raised by the ex-gay ad. Indeed it may well have redirected scarce resources and emotional energy of the LGBT movement away from these other issues.

Yet the message that the pro-gay response ads do promote is the core principle of the movement: that gay men and lesbians are deserving of equal treatment under the law. It is the same message underlying all of the activism of the LGBT movement, and since the ex-gay ads had captured so much public attention, it behooved the movement to take advantage of the expanded audience. In producing the ex-gay ads, the Christian antigay, pro-family movement created a unique opportunity for the lesbian and gay movement, introducing a clear, issuespecific, controversial message to which they could respond. They provided a disputable set of claims, stirred up national attention to lesbian and gay identities, and in doing so, they invited a response from the LGBT movement. The antigay movement momentarily redirected the focus of lesbian and gay activists away from the issues and claims of movement organizations and toward 
the issues as the opposing movement defined them. Lesbian and gay movement claims briefly shifted away from the issues of same-sex marriage, hate crimes bills, and anti-discrimination protections, to claims that reasserted that lesbians and gay men are neither sinful nor diseased, but rather are an oppressed minority under attack by the Christian Right. However, this redirection also provided increased media attention, a reinvigorated set of activists, and the anger and energy that sustains movement actions.

I assert that the ex-gay ads were not nearly as harmful to the LGBT movement goals as it may seem at first glance. The introduction of ex-gay conversion therapy to a mainstream audience was an innovative tactic on the part of the Christian antigay, pro-family movement. Though the ads were intended to be a major new strategy of this movement, the overall impact of these ads on the cultural context was negligible. Since 1998, mainstream discourse about lesbian and gay identity has not adopted the homosexuality as choice or the homosexuality as condition frame, nor has the practice of ex-gay conversion therapy gained widespread acceptance as a legitimate or effective treatment. The ad campaign has had no discernible impact on public opinion about homosexuality. ${ }^{\mathrm{iii}}$ The cultural contests over the discourse surrounding homosexuality did not have as big an impact as the Christian antigay, pro-family movement might have hoped.

The impact on the political context is also questionable. Though neither the ex-gay ads or the pro-gay responses did much to change people's minds about homosexuality, they were more effective in providing those with already strong opinions on the matter with additional discursive tools. Thus, politicians and bureaucrats who agree with antigay, pro-family activists now have a new justification for their position. Whether this will negatively impact the LGBT movement's ability to implement pro-gay legislation remains to be seen. The back and forth dialogue between 
the two opposing movements seems to keep the issue of lesbian and gay rights present on the public agenda, but keeps it from progressing too far in one direction or the other. This ad campaign is a clear example of the Christian antigay, pro-family movement's ability to call much attention to the issue of homosexuality, without advancing much social change. The LGBT movement is in a similar stasis, working very hard to gain little ground. Perhaps this is the ultimate fate of opposing movements: while they can often prevent the other side from affecting social change, it is difficult to make any significant progress toward their own goals. At the end of this war of words fought on the pages of newspapers in the summer of 1998, these two movements found themselves very near where they started. 
ENDNOTES 
${ }^{\mathrm{i}} \mathrm{A}$ year later, gay and lesbian activists were delighted that he was spotted in a gay bar in Washington DC ("Maybe not so 'Ex' after All," 2000).

${ }^{\text {ii } I n ~ s o m e ~ c a s e s, ~ e x-g a y ~ t h e r a p y ~ a n d ~ a n t i g a y ~ a c t i v i s m ~ a r e ~ l i n k e d ~ o r g a n i z a t i o n a l l y ~ a n d ~ f u n d e d ~ b y ~ t h e ~}$ same conglomerate Christian ministry organization. However, they are generally run as separate organizations.

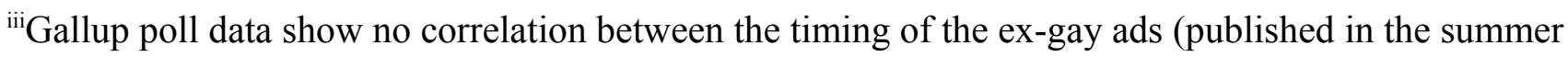
of 1998) and the number of people who answer in the affirmative to the question "Do you feel that homosexuality should be considered an acceptable alternative lifestyle or not?" Polls asking this question in April 1997 show that 43\% of respondents answer affirmatively, as do $50 \%$ of respondents in February 1999, and 52\% of respondents in May 2001. 